\title{
RELATIONSHIPS BETWEEN HEPCIDIN, INTERLEUKIN-6 AND PARAMETERS OF IRON METABOLISM IN PREGNANT WOMEN
}

\author{
Tsvetelina V. PETKOVA-MARINOVA ${ }^{1 凶}$, Boryana K. RUSEVA ${ }^{1}$, Bozhanka PANEVA-BARZASHKA ${ }^{2}$, \\ Milena A. ATANASOVA ${ }^{3}$, Petya V. DRAGOMIROVA ${ }^{3}$, Pavlina D. LALEVA ${ }^{4}$ \\ ${ }^{1}$ Department of Physiology, Faculty of Medicine, Medical University - Pleven, Bulgaria \\ ${ }^{2}$ Medical Center for Reproductive Medicine - Pleven, Bulgaria \\ ${ }^{3}$ Department of Biology, Faculty of Medicine, Medical University - Pleven, Bulgaria. \\ ${ }^{4}$ Department of Pre-clinical and Clinical Sciences, Faculty of Pharmacy, Medical University - Pleven, \\ Bulgaria
}

\author{
Received 09 Nov 2020, Accepted 21 Nov 2020 \\ https://doi.org/10.31688/ABMU.2020.55.4.02
}

\section{Abstract}

Introduction. Iron homeostasis has been extensively studied in the recent years. The factors regulating hepcidin secretion and the significance of hepcidin during pregnancy have not been fully clarified.

The objective of the study was to investigate the serum concentrations of hepcidin and interleukin-6 (IL-6) and their relationships to parameters of iron metabolism in women with low-risk and high-risk pregnancies.

Material and methods. The study involved 40 pregnant women distributed in two groups: high-risk pregnancies (HRP, $n=20$ ) and low-risk pregnancies (LRP, n=20). The HRP were associated with chronic inflammatory disorders and reproductive failures. We evaluated the red blood cell count, hemoglobin ( $\mathrm{Hb})$ concentration, hematocrit (Hct), erythrocyte indices, serum concentrations of hepcidin, IL-6, ferritin (Ferr) and iron $(\mathrm{Fe})$, the total iron binding capacity (TIBC)

\section{Résumé}

Relations entre l'hepcidine, l'interleukine- 6 et les paramètres du métabolisme du fer chez les femmes enceintes

Introduction. La régulation de l'homéostasie du fer a été largement étudiée ces dernières années. Les facteurs régulateurs de la sécrétion d'hepcidine et la signification de l'hepcidine pendant la grossesse n'ont pas été entièrement clarifiées.

L'objectif de l'étude était d'explorer les concentrations sériques d'hepcidine et d'interleukine-6 (IL-6) et leurs relations avec les paramètres du métabolisme du fer chez les femmes aux grossesses à faible et à haut risque.

Matériel et méthodes. L'étude a porté sur 40 femmes enceintes réparties en deux groupes: les grossesses à haut risque $(\mathrm{GHR}, \mathrm{n}=20)$ et les grossesses à faible risque (GFR, $n=20)$. Les GHR étaient associées 
and transferrin saturation (SatTf) twice, at the beginning of the second and third trimester of pregnancy.

Results. We found significantly higher serum Ferr and lower TIBC in HRP than in the controls at the beginning of the second trimester $(\mathrm{p}<0.05)$. Significant decline in serum Ferr and rise in TIBC were observed during pregnancy in both groups, whereas decrease in SatTf was found only in LRP ( $p<0.05)$. In HRP, serum concentrations of IL-6 were negatively related to serum $\mathrm{Fe}$ and SatTf, and positively - to $\mathrm{Hb}$ concentration, while serum hepcidin was negatively related to $\mathrm{Hb}$ concentration and Hct $(\mathrm{p}<0.05)$. A significant positive relationship between serum hepcidin and IL- 6 was found in $\operatorname{LRP}(\mathrm{p}=0.038)$.

Conclusions. There are significant relationships between IL- 6 and hepcidin production and parameters of iron metabolism in pregnancy.

Keywords: hepcidin, IL-6, iron homeostasis, pregnant women.

\author{
Abbreviations list: \\ ANOVA - analysis of variance \\ BMI - body mass index \\ CRP - C-reactive protein \\ ECLIA - electrochemiluminescence immunoassay \\ ELISA - enzyme-linked immunosorbent assay \\ $\mathrm{Fe}-$ iron \\ Ferr - ferritin \\ g.w. - gestation week \\ $\mathrm{Hb}$ - hemoglobin \\ Hct - hematocrit \\ Hepc - hepcidin \\ HRP - high-risk pregnancies \\ IL-6 - interleukin-6 \\ IQR - interquartile range \\ LRP - low-risk pregnancies \\ $\mathrm{MCH}$ - mean cell hemoglobin \\ $\mathrm{MCHC}$ - mean cell hemoglobin concentration \\ $\mathrm{MCV}$ - mean cell volume \\ RBC - red blood cell count \\ SatTf - saturation of transferrin \\ $\mathrm{SD}$ - standard deviation \\ SE - standard error \\ sTfR - soluble transferrin receptor \\ TIBC - total iron binding capacity
}

\section{INTRODUCTION}

Iron homeostasis throughout pregnancy is essential for the health of both mother and fetus.

Recent data indicate that the peptide hepcidin, discovered in 2001 and initially identified as an antimicrobial protein, is the major regulator of systemic à des troubles inflammatoires chroniques et à des échecs de reproduction. Nous avons évalué le nombre de globules rouges, la concentration d'hémoglobine $(\mathrm{Hb})$, l'hématocrite $(\mathrm{Hct})$, les indices érythrocytaires, les concentrations sériques d'hepcidine, d'IL-6, de ferritine (Ferr) et de fer ( $\mathrm{Fe}$ ), la capacité totale de liaison du fer (TIBC) et la saturation de la transferrine (SatTf) deux fois, au début des deuxième et troisième trimestres de la grossesse.

Résultats. Nous avons trouvé une Ferr sérique largement plus élevée et un TIBC plus bas dans la GHR que chez les témoins au début du deuxième trimestre $(p<0,05)$. Une diminution significative de la Ferr sérique et une augmentation du TIBC ont été observées pendant la grossesse dans les deux groupes, alors qu'un abaissement de SatTf n'a été trouvé que dans la GFR $(\mathrm{p}<0,05)$. Dans la GHR, les concentrations sériques d'IL-6 étaient négativement liées au Fe sérique et SatTf, et positivement à la concentration d'Hb, tandis que l'hepcidine sérique était négativement liée à la concentration d'Hb et Hct $(p<0,05)$. Une relation positive significative entre l'hepcidine sérique et l'IL-6 a été trouvée dans LRP $(\mathrm{p}=0,038)$.

Conclusions. Il existe des relations significatives entre la production d'IL-6 et d'hepcidine et les paramètres du métabolisme du fer pendant la grossesse.

Mots-clés: l'hepcidine, l'interleukine-6, homéostasie du fer, les femmes enceintes.

iron homeostasis ${ }^{1,2}$. It is the sole hormone found to be involved in the systemic regulation of iron metabolism $^{3}$. Hepcidin acts as a negative regulator of intestinal iron absorption and body iron distribution ${ }^{2,4}$. It has also been shown to affect transplacental transfer of iron during pregnancy $y^{5-7}$, but the exact mechanism of this interaction is not fully understood. Hepcidin 
synthesis and secretion are regulated by a wide range of factors, such as body iron status, erythropoietic activity, partial pressure of oxygen, and inflammation ${ }^{4}$. At present, it is considered that the body iron status regulates the production of hepcidin via two separate signals, provided by circulating iron and iron stores ${ }^{4}$. Inflammation induces hepcidin synthesis, an effect mediated by the proinflammatory cytokine interleukin-6 (IL-6) ${ }^{8,9}$. So far, the significance of factors regulating hepcidin secretion during pregnancy has not yet been clarified.

Findings on serum hepcidin concentrations and their dynamic changes during pregnancy are limited and somewhat contradictory. It has been proved that in healthy pregnant women, with uncomplicated pregnancies, serum concentrations of hepcidin are lower than in non-pregnant women ${ }^{10,11}$. Moreover, in complicated, high-risk pregnancies associated with inflammatory conditions, obesity, and preeclampsia, significantly higher serum hepcidin concentrations have been found than in low-risk pregnancies ${ }^{12-16}$. In contrast to these data, a recently conducted study reported significantly lower serum hepcidin levels in preeclamptic women than in healthy pregnant women ${ }^{17}$. Besides, high-risk pregnancies have been associated with diminished iron bioavailability to the mother and fetus, probably caused by the effects of hepcidin ${ }^{13,18}$.

Longitudinal assessment has indicated that serum hepcidin concentrations gradually decline throughout pregnancy, reaching the lowest and even undetectable levels in the third trimester ${ }^{11,19,20}$. However, the factors responsible for suppression of hepcidin production and hepcidin dynamics during pregnancy have not been clarified. Fetal iron requirements, which increase over pregnancy and become highest in the third trimester, have been proposed as a possible factor for the progressive decrease in maternal hepcidin level ${ }^{7,18}$. The results of a study suggest that the lower and even undetectable maternal serum hepcidin at delivery is associated with a greater transplacental transfer of iron to the fetus ${ }^{6}$. It is now considered that suppression of hepcidin production during pregnancy allows maximal iron bioavailability to the mother and fetus ${ }^{18,21}$.

The regulatory mechanism of inhibition of hepcidin production during low-risk pregnancy has not yet been completely elucidated. In the attempt to elucidate the factors involved in hepcidin regulation during pregnancy, different studies have assessed relationships between the levels of hepcidin and parameters of iron metabolism. Each of these markers has been used to characterize distinct aspects of iron metabolism: serum ferritin (Ferr) for the assessment of iron stores, serum iron $(\mathrm{Fe})$ and saturation of transferrin (SatTf) as measures of transport iron available for erythropoiesis, total iron binding capacity (TIBC) as an indicator of the plasma capacity for binding and transport of iron, soluble transferrin receptor (sTfR) for the evaluation of erythropoietic activity, and haemoglobin $(\mathrm{Hb})$ concentration as a parameter reflecting the amount of functional iron in the body $y^{22-25}$. Results are inconsistent. Some studies have established positive correlations of serum hepcidin levels with serum Ferr, serum Fe, SatTf, and Hb concentration and negative correlations with serum transferrin, TIBC and sTfR $6,7,11,16,19$. Other studies, however, have not confirmed significant correlations of hepcidin levels with serum Ferr, serum Fe, SatTf, sTfR and $\mathrm{Hb}$ concentration ${ }^{10,17,26}$. These results suggest that either changes in the maternal iron status and erythropoietic activity during pregnancy, or unknown pregnancy-specific regulators could be involved in the regulation of hepcidin synthesis and secretion ${ }^{18}$.

Moreover, other data indicate that fetal factors might also exert influence on maternal hepcidin production. In a study of obese and lean pregnant women, maternal hepcidin has been negatively related to fetal cord blood serum Fe and SatTf ${ }^{13}$. Data from an animal study indicate that it is the fetal, rather than the maternal iron stores that determine maternal hepcidin production during pregnancy $y^{27}$.

THE OBJECTIVE OF THE STUDY was to investigate serum concentrations of hepcidin and IL- 6 and their relationships to parameters of iron metabolism in women with low-risk and high-risk pregnancies.

\section{Material AND MEthods}

The present study was approved by the Committee on Ethics of Scientific research at Medical University Pleven (Bulgaria). All the procedures and experiments of the study were performed in conformity with the ethical standards in the Helsinki Declaration of 1975, as revised in 2000, for biomedical research involving human subjects.

We conducted a longitudinal prospective study between October 2015 and May 2016. A total of 40 pregnant women with a mean age of $28.86 \pm 4.8$ years (range 21.0-39.0 years) were distributed in two groups: a group of high-risk pregnancies $(n=20)$ and a control group of low-risk pregnancies $(n=20)$. Written informed consent was obtained from all participants prior to participation. Pregnant women who met the following criteria at the time of registration were eligible to the high-risk pregnancy group: pregnancies complicated by chronic inflammatory conditions, including autoimmune diseases, obesity, diabetes mellitus, and preeclampsia. The characteristics that qualified women for inclusion in the control group 
were singleton pregnancies uncomplicated by the afore-mentioned conditions.

The high-risk pregnancies in the present study were associated with conditions characterized by chronic inflammation: autoimmune thyroiditis $(n=8)$, obesity $(n=3)$ and preceded by reproductive failures (infertility, spontaneous abortions; $n=13$ ). The current pregnancy was achieved by assisted reproductive technology procedures in 10 of the women with high-risk pregnancies [conventional in vitro fertilization $(n=9)$ and intrauterine insemination $(n=1)]$. One woman had a twin pregnancy and the others - singleton pregnancies.

Anthropometric measurements were performed and venous blood specimens for laboratory analysis were collected at each examination. Anthropometric measurements included determination of body weight and height by a standard methodology and calculation of body mass index (BMI). Women were examined twice, at the beginning of the second trimester (16-18 gestation weeks) and at the beginning of the third trimester (30-32 gestation weeks).

Whole-blood samples were used for determination of hematological indicators and extraction of serum. Serum samples were distributed into cryogenic vials and stored at $-70^{\circ} \mathrm{C}$ prior to analysis. Serum samples were used for determination of serum concentrations of hepcidin and the inflammatory marker
IL-6, and evaluation of biochemical markers of iron metabolism.

Iron metabolism was assessed by blood and serum parameters as follows: red blood cell count (RBC), Hb concentration, hematocrit (Hct), erythrocyte indices - mean cell volume (MCV), mean cell hemoglobin $(\mathrm{MCH})$ and mean cell hemoglobin concentration (MCHC), and biochemical markers serum Ferr, serum concentration of Fe, TIBC and SatTf.

Hematological parameters were determined on hematological analyzer MICROS. Serum concentrations of hepcidin 25 (Hepc25) and IL-6 were quantified by sandwich ELISA methods using commercial kits from Cusabio (Cusabio Biotech Co., Ltd, Wuhan, Hubei Province, China) and Diaclone (Diaclone SAS, Besançon Cedex, France), respectively, according to the manufacturers' protocols. Serum Ferr analysis was performed by electrochemiluminescence immunoassay (ECLIA) on Cobas E 411 immunoassay analyzer. FerroZine method was applied to determine serum Fe and TIBC with subsequent calculation of percent SatTf.

Data were processed by statistical package STATGRAPHICS Centurion XVI. Differences between the study groups in the laboratory parameters with a normal distribution were tested by analysis of variance (One-way ANOVA), and in non-normally distributed variables - by H-test of Kruskal-Wallis. Relationships between numerical variables were assessed by Pearson's correlation analysis. Statistical

Table 1. Results of investigated laboratory parameters for the study groups of pregnant women with LRP and HRP at the beginning of the second and the third trimesters

\begin{tabular}{ccccc}
\hline \multirow{2}{*}{$\begin{array}{c}\text { Laboratory } \\
\text { parameters }\end{array}$} & LRP & HRP & LRP & Ho-32 g.w. \\
\cline { 2 - 5 } & $3.86 \pm 0.08$ & $3.79 \pm 0.09$ & $3.67 \pm 0.08$ & $3.6 \pm 0.1$ \\
\hline $\mathrm{RBC}\left(\mathrm{x} 10^{12} / \mathrm{L}\right)^{\S}$ & $116.86 \pm 2.27$ & $115.62 \pm 2.3$ & $113.31 \pm 1.76$ & $113.33 \pm 2.05$ \\
\hline $\mathrm{Hb}(\mathrm{g} / \mathrm{L})^{\S}$ & $0.35 \pm 0.01$ & $0.34 \pm 0.01$ & $0.33 \pm 0.01$ & $0.33 \pm 0.01$ \\
\hline $\mathrm{Hct}(\mathrm{L} / \mathrm{L})^{\S}$ & $89.39 \pm 1.44$ & $87.68 \pm 1.61$ & $90.65 \pm 1.33$ & $90.29 \pm 1.11$ \\
\hline $\mathrm{MCV}(\mathrm{fL})^{\S}$ & $30.18 \pm 0.55$ & $30.17 \pm 0.73$ & $30.7 \pm 0.55$ & $31.4 \pm 0.63$ \\
\hline $\mathrm{MCH}(\mathrm{pg})^{\S}$ & $338.07 \pm 2.18$ & $344.25 \pm 5.24$ & $338.54 \pm 2.51$ & $347.6 \pm 4.48$ \\
\hline $\mathrm{MCHC}(\mathrm{g} / \mathrm{L})^{\S}$ & $26.27(21.28-45.28)$ & $62.15(43.68-91.0)^{*}$ & $12.67(11.27-19.16)^{\dagger}$ & $21.48(11.69-37.98)^{\dagger}$ \\
\hline Serum Ferr $(\mu \mathrm{g} / \mathrm{L})^{\ddagger}$ & $11.75 \pm 1.73$ & $18.98 \pm 1.71$ & $16.5 \pm 1.17$ & $17.73 \pm 2.17$ \\
\hline Serum Fe $(\mu \mathrm{mol} / \mathrm{L})^{\S}$ & $71.13(68.31-77.22)$ & $63.36(57.25-68.17)^{*}$ & $84.69(78.53-91.0)^{\dagger}$ & $87.43(75.15-92.9)^{\dagger}$ \\
\hline $\mathrm{TIBC}(\mu \mathrm{mol} / \mathrm{L})^{\ddagger}$ & $30.53 \pm 2.95$ & $30.42 \pm 2.96$ & $19.57 \pm 1.46$ & $21.68 \pm 3.21$ \\
\hline SatTf $(\%)^{\uparrow}$ & $13.93 \pm 4.95$ & $15.04 \pm 4.63$ & $12.78 \pm 4.78$ & $26.31 \pm 7.73$ \\
\hline Serum Hepc $(\mathrm{ng} / \mathrm{mL})^{\S}$ & $0.59(0.39-1.02)$ & $0.68(0.37-1.45)$ & $0.54(0.42-1.02)$ & $0.31(0.08-0.49)$ \\
\hline Serum $\mathrm{IL}-6(\mathrm{pg} / \mathrm{mL})^{\ddagger}$ & &
\end{tabular}

${ }^{\S}$ Data are expressed as means $\pm \mathrm{SE}$

${ }^{*}$ Data are expressed as median (IQR)

${ }^{*} p<0.05$ when comparing the results for the study group of LRP with HRP at the same trimester

${ }^{\dagger} \mathrm{p}<0.05$ when comparing the results for the $2^{\text {nd }}$ trimester with the $3^{\text {rd }}$ trimester of the same study group

Abbreviations: Fe - iron; Ferr - ferritin; g.w. - gestation week; Hb - hemoglobin concentration; Hct - hematocrit;

Hepc - hepcidin; HRP - high-risk pregnancies; IL-6 - interleukin-6; IQR - interquartile range; LRP - low-risk pregnancies; $\mathrm{MCH}$ - mean cell hemoglobin; MCHC - mean cell hemoglobin concentration; MCV - mean cell volume; RBC - red blood cell count; SatTf - saturation of transferrin; SE - standard error; TIBC - total iron binding capacity 
significance was indicated by $\mathrm{p}<0.05$. Values are expressed as mean \pm standard error $(\mathrm{SE})$ or median [interquartile range (IQR)] according to the type of distribution, unless otherwise indicated.

\section{RESULTS}

The mean age was $28.13 \pm 5.1$ years (median 26.0 years) among the women with high-risk pregnancies and $29.45 \pm 4.59$ years (median 28.0 years) among the women with low-risk pregnancies. We did not find any significant differences between the two study groups in relation to age $(p=0.418)$. Mean BMI values did not significantly differ between the groups of high-risk and low-risk pregnancies either at the time of registration $\left(26.44 \pm 1.56 \mathrm{~kg} / \mathrm{m}^{2}\right.$ vs. $23.26 \pm 0.76 \mathrm{~kg} /$ $\left.\mathrm{m}^{2} ; \mathrm{p}=0.073\right)$ or at their follow-up $\left(26.96 \pm 0.97 \mathrm{~kg} / \mathrm{m}^{2}\right.$ vs. $\left.27.08 \pm 0.57 \mathrm{~kg} / \mathrm{m}^{2} ; \mathrm{p}=0.915\right)$.
We found that median serum Ferr concentration in the group of high-risk pregnancies was significantly higher than in the controls with low-risk pregnancy $(\mathrm{p}=0.001)$ at the beginning of the second trimester (Table 1). With progression of the pregnancy serum Ferr showed a significant decline in both study groups of high-risk pregnancy $(\mathrm{p}=0.0002)$ and low-risk pregnancy $(\mathrm{p}=0.002)$. At the beginning of the third trimester, median serum levels of Ferr were not significantly different between the groups $(\mathrm{p}=0.113)$.

The total iron binding capacity presented with significantly lower median value in the high-risk pregnancies than in the controls at the beginning of the second trimester $(\mathrm{p}=0.004)$. With progression of the pregnancy TIBC increased significantly in the group of high-risk pregnancies $(\mathrm{p}=0.0002)$, and a similar rise was observed in the control group ( $\mathrm{p}=0.006)$. At the

Table 2. Correlations between serum concentrations of Hepc and IL-6 and parameters of iron metabolism for the study groups of pregnant women with LRP and HRP at the beginning of the second and the third trimesters

\begin{tabular}{|c|c|c|c|c|c|c|c|c|c|}
\hline \multirow{3}{*}{$\begin{array}{l}\text { Laboratory } \\
\text { parameters }\end{array}$} & \multicolumn{5}{|c|}{$16-18$ g.w.s } & \multicolumn{4}{|c|}{ 30-32 g.w. } \\
\hline & \multicolumn{3}{|c|}{$L R P$} & \multicolumn{2}{|c|}{ HRP } & \multicolumn{2}{|c|}{ LRP } & \multicolumn{2}{|c|}{ HRP } \\
\hline & & $\begin{array}{l}\text { Serum Hepc } \\
(\mathrm{ng} / \mathrm{mL})\end{array}$ & $\begin{array}{c}\text { Serum } \\
\text { IL-6 } \\
(p g / m L) \\
\end{array}$ & $\begin{array}{c}\text { Serum } \\
\text { Hepc } \\
(n g / m L)\end{array}$ & $\begin{array}{l}\text { Serum IL-6 } \\
(\mathrm{pg} / \mathrm{mL})\end{array}$ & $\begin{array}{c}\text { Serum Hepc } \\
(n g / m L)\end{array}$ & $\begin{array}{l}\text { Serum IL-6 } \\
(\mathrm{pg} / \mathrm{mL})\end{array}$ & $\begin{array}{l}\text { Serum Hepc } \\
(\mathrm{ng} / \mathrm{mL})\end{array}$ & $\begin{array}{l}\text { Serum IL-6 } \\
(\mathrm{pg} / \mathrm{mL})\end{array}$ \\
\hline $\mathrm{RBC}\left(\mathrm{x} 10^{12} / \mathrm{L}\right)$ & $\begin{array}{l}\mathrm{r} \\
\mathrm{p}\end{array}$ & $\begin{array}{c}0.008 \\
0.98\end{array}$ & $\begin{array}{c}-0.403 \\
0.173\end{array}$ & $\begin{array}{c}-0.462 \\
0.112\end{array}$ & & & $\begin{array}{l}-0.017 \\
0.955\end{array}$ & $\begin{array}{l}-0.151 \\
0.641\end{array}$ & $\begin{array}{c}0.361 \\
0.25\end{array}$ \\
\hline $\mathrm{Hb}(\mathrm{g} / \mathrm{L})$ & $\begin{array}{l}\mathrm{r} \\
\mathrm{p}\end{array}$ & $\begin{array}{c}-0.284 \\
0.371\end{array}$ & $\begin{array}{l}0.087 \\
0.777\end{array}$ & $\begin{array}{c}-0.262 \\
0.387\end{array}$ & $\begin{array}{c}-0.059 \\
0.849\end{array}$ & $\begin{array}{l}0.033 \\
0.914\end{array}$ & $\begin{array}{l}0.054 \\
0.861\end{array}$ & $\begin{array}{l}-0.646 \\
0.023^{*}\end{array}$ & $\begin{array}{l}0.685 \\
0.014^{*}\end{array}$ \\
\hline $\operatorname{Hct}(\mathrm{L} / \mathrm{L})$ & $\begin{array}{l}\mathrm{r} \\
\mathrm{p} \\
\end{array}$ & $\begin{array}{c}-0.308 \\
0.33 \\
\end{array}$ & $\begin{array}{c}-0.012 \\
0.97 \\
\end{array}$ & $\begin{array}{c}-0.399 \\
0.177 \\
\end{array}$ & $\begin{array}{c}-0.226 \\
0.457 \\
\end{array}$ & $\begin{array}{l}-0.058 \\
0.852 \\
\end{array}$ & $\begin{array}{l}0.087 \\
0.778 \\
\end{array}$ & $\begin{array}{l}-0.654 \\
0.021^{*} \\
\end{array}$ & $\begin{array}{l}0.528 \\
0.078 \\
\end{array}$ \\
\hline $\mathrm{MCV}(\mathrm{fL})$ & $\begin{array}{l}\mathrm{r} \\
\mathrm{p} \\
\end{array}$ & $\begin{array}{c}-0.422 \\
0.172 \\
\end{array}$ & $\begin{array}{c}0.41 \\
0.164 \\
\end{array}$ & $\begin{array}{l}0.012 \\
0.971 \\
\end{array}$ & $\begin{array}{c}-0.556 \\
0.061 \\
\end{array}$ & $\begin{array}{c}-0.085 \\
0.783 \\
\end{array}$ & $\begin{array}{c}-0.004 \\
0.989 \\
\end{array}$ & $\begin{array}{c}-0.193 \\
0.593 \\
\end{array}$ & $\begin{array}{c}-0.429 \\
0.216 \\
\end{array}$ \\
\hline $\mathrm{MCH}(\mathrm{pg})$ & $\begin{array}{l}\mathrm{r} \\
\mathrm{p}\end{array}$ & $\begin{array}{l}-0.315 \\
0.319\end{array}$ & $\begin{array}{l}0.456 \\
0.117\end{array}$ & $\begin{array}{l}0.034 \\
0.917\end{array}$ & $\begin{array}{l}-0.457 \\
0.136\end{array}$ & $\begin{array}{l}0.069 \\
0.823\end{array}$ & $\begin{array}{l}0.026 \\
0.933\end{array}$ & $\begin{array}{l}0.012 \\
0.974\end{array}$ & $\begin{array}{l}-0.135 \\
0.709\end{array}$ \\
\hline $\operatorname{MCHC}(\mathrm{g} / \mathrm{L})$ & $\begin{array}{l}\mathrm{r} \\
\mathrm{p}\end{array}$ & $\begin{array}{l}0.194 \\
0.545 \\
\end{array}$ & $\begin{array}{l}0.463 \\
0.111 \\
\end{array}$ & $\begin{array}{l}0.047 \\
0.884 \\
\end{array}$ & $\begin{array}{l}-0.03 \\
0.926 \\
\end{array}$ & $\begin{array}{l}0.354 \\
0.235 \\
\end{array}$ & $\begin{array}{l}0.097 \\
0.754 \\
\end{array}$ & $\begin{array}{l}0.257 \\
0.474 \\
\end{array}$ & $\begin{array}{l}0.168 \\
0.642 \\
\end{array}$ \\
\hline $\begin{array}{c}\text { Serum Ferr } \\
(\mu \mathrm{g} / \mathrm{L})\end{array}$ & $\begin{array}{l}\mathrm{r} \\
\mathrm{p}\end{array}$ & $\begin{array}{c}-0.454 \\
0.138 \\
\end{array}$ & $\begin{array}{c}-0.421 \\
0.152 \\
\end{array}$ & $\begin{array}{c}-0.031 \\
0.915 \\
\end{array}$ & $\begin{array}{l}-0.128 \\
0.663 \\
\end{array}$ & $\begin{array}{l}0.173 \\
0.555 \\
\end{array}$ & $\begin{array}{l}0.159 \\
0.588 \\
\end{array}$ & $\begin{array}{l}0.008 \\
0.977 \\
\end{array}$ & $\begin{array}{c}-0.199 \\
0.496 \\
\end{array}$ \\
\hline $\begin{array}{l}\text { Serum Fe } \\
(\mu \mathrm{mol} / \mathrm{L})\end{array}$ & $\begin{array}{l}\mathrm{r} \\
\mathrm{p}\end{array}$ & $\begin{array}{c}-0.395 \\
0.204 \\
\end{array}$ & $\begin{array}{c}-0.034 \\
0.912 \\
\end{array}$ & $\begin{array}{c}-0.127 \\
0.665 \\
\end{array}$ & $\begin{array}{l}-0.697 \\
0.006^{*} \\
\end{array}$ & $\begin{array}{c}-0.114 \\
0.697 \\
\end{array}$ & $\begin{array}{l}0.207 \\
0.478 \\
\end{array}$ & $\begin{array}{c}-0.067 \\
0.821 \\
\end{array}$ & $\begin{array}{l}0.395 \\
0.163 \\
\end{array}$ \\
\hline TIBC $(\mu \mathrm{mol} / \mathrm{L})$ & $\begin{array}{l}\mathrm{r} \\
\mathrm{p}\end{array}$ & $\begin{array}{l}0.448 \\
0.144 \\
\end{array}$ & $\begin{array}{l}0.441 \\
0.132 \\
\end{array}$ & $\begin{array}{l}0.073 \\
0.805 \\
\end{array}$ & $\begin{array}{c}-0.025 \\
0.932 \\
\end{array}$ & $\begin{array}{l}0.193 \\
0.509 \\
\end{array}$ & $\begin{array}{l}0.312 \\
0.278 \\
\end{array}$ & $\begin{array}{c}-0.156 \\
0.593 \\
\end{array}$ & $\begin{array}{c}-0.09 \\
0.761 \\
\end{array}$ \\
\hline SatTf (\%) & $\begin{array}{l}\mathrm{r} \\
\mathrm{p}\end{array}$ & $\begin{array}{c}-0.458 \\
0.134 \\
\end{array}$ & $\begin{array}{c}-0.201 \\
0.51\end{array}$ & $\begin{array}{c}-0.143 \\
0.627\end{array}$ & $\begin{array}{l}-0.598 \\
0.024^{*} \\
\end{array}$ & $\begin{array}{c}-0.178 \\
0.544 \\
\end{array}$ & $\begin{array}{l}0.061 \\
0.836 \\
\end{array}$ & $\begin{array}{l}-0.035 \\
0.905 \\
\end{array}$ & $\begin{array}{l}0.385 \\
0.175 \\
\end{array}$ \\
\hline $\begin{array}{l}\text { Serum Hepc (ng/ } \\
\text { mL) }\end{array}$ & $\begin{array}{l}\mathrm{r} \\
\mathrm{p}\end{array}$ & 1 & $\begin{array}{l}0.398 \\
0.201 \\
\end{array}$ & 1 & $\begin{array}{l}0.061 \\
0.835 \\
\end{array}$ & 1 & $\begin{array}{l}0.558 \\
0.038^{*}\end{array}$ & 1 & $\begin{array}{l}-0.166 \\
0.571 \\
\end{array}$ \\
\hline $\begin{array}{c}\text { Serum IL-6 (pg/ } \\
\mathrm{mL})\end{array}$ & $\begin{array}{l}\mathrm{r} \\
\mathrm{p}\end{array}$ & $\begin{array}{l}0.398 \\
0.201\end{array}$ & 1 & $\begin{array}{l}0.061 \\
0.835\end{array}$ & 1 & $\begin{array}{l}0.558 \\
0.038^{*}\end{array}$ & 1 & $\begin{array}{l}-0.166 \\
0.571\end{array}$ & 1 \\
\hline
\end{tabular}

* Significance level, $\mathrm{p}<0.05$

Abbreviations: Fe - iron; Ferr - ferritin; g.w. - gestation week; Hb - hemoglobin concentration; Hct - hematocrit; Hepc hepcidin; HRP - high-risk pregnancies; IL-6 - interleukin-6; LRP - low-risk pregnancies; MCH - mean cell hemoglobin; $\mathrm{MCHC}$ - mean cell hemoglobin concentration; MCV - mean cell volume; RBC - red blood cell count; SatTf - saturation of transferrin; TIBC - total iron binding capacity 


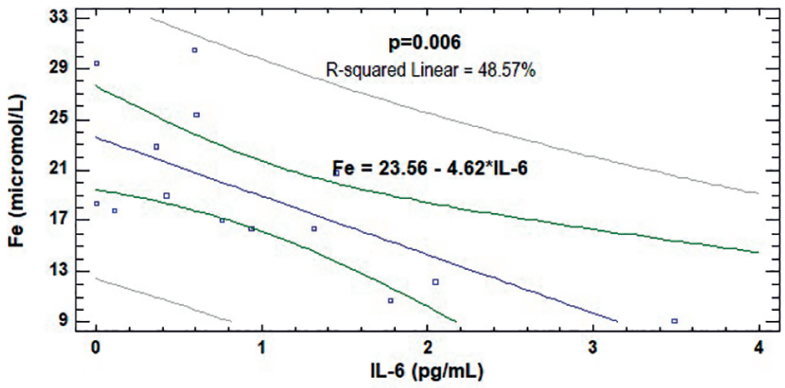

Figure 1. Regression function and scatter diagram representing the relationship between serum concentrations of Fe and IL-6 in the group of HRP at the beginning of the second trimester. Legend: $\mathrm{Fe}$ - iron;

HRP - high-risk pregnancies; IL-6 - interleukin-6

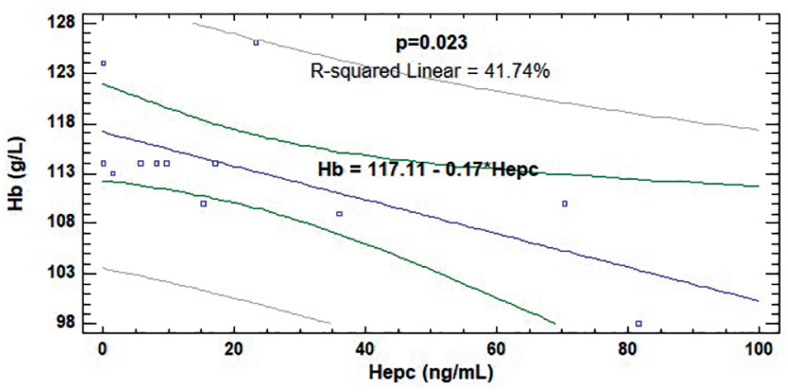

Figure 3. Regression function and scatter diagram representing the relationship between $\mathrm{Hb}$ concentrations and serum levels of Hepc in the group of HRP at the beginning of the third trimester. Legend: $\mathrm{Hb}$ - hemoglobin concentration; Hepc - hepcidin; HRP - high-risk pregnancies

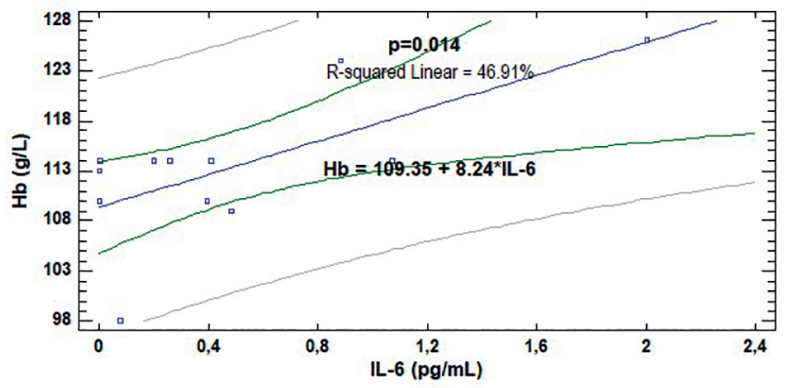

Figure 5. Regression function and scatter diagram representing the relationship between $\mathrm{Hb}$ concentrations and serum levels of IL-6 in the group of HRP at the beginning of the third trimester.

Legend: $\mathrm{Hb}$ - hemoglobin concentration; HRP - high-risk pregnancies; IL-6 - interleukin-6

beginning of the third trimester, median TIBC did not significantly differ between the study groups $(\mathrm{p}=0.801)$.

Mean SatTf significantly declined with progression of the pregnancy only in the control group $(\mathrm{p}=0.017)$, while in the group of high-risk pregnancies no significant dynamical changes in SatTf were found

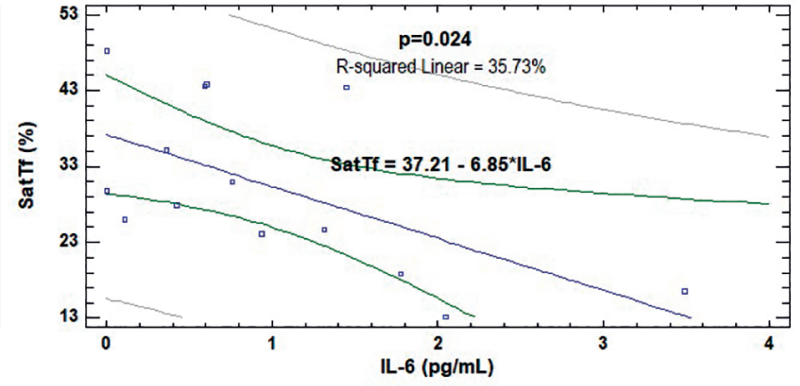

Figure 2. Regression function and scatter diagram representing the relationship between SatTf and IL-6 in the group of HRP at the beginning of the second trimester. Legend: HRP - high-risk pregnancies; IL-6 - interleukin-6; SatTf - saturation of transferrin

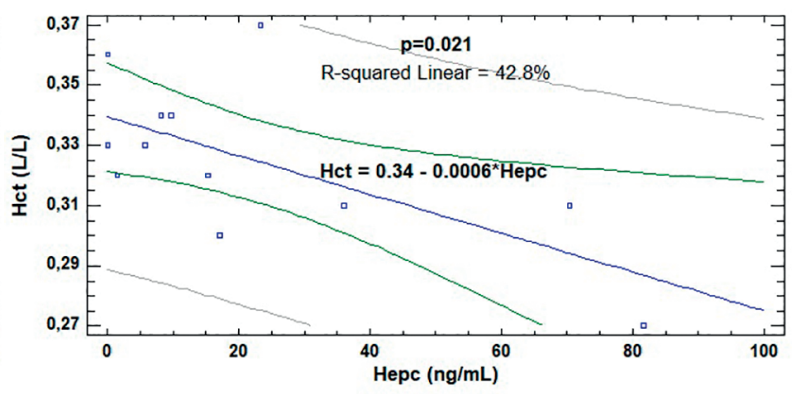

Figure 4. Regression function and scatter diagram representing the relationship between Hct and serum concentrations of Hepc in the group of HRP at the beginning of the third trimester.

Legend: Hct - hematocrit; Hepc - hepcidin; HRP - high-risk pregnancies

$(\mathrm{p}=0.772)$. Mean SatTf values were not significantly different between the high-risk and low-risk pregnancy groups either at the initial evaluation or at the follow-up examination ( $p>0.05)$.

We did not observe any statistically significant differences in the mean serum hepcidin concentrations between the study groups at either stages of pregnancy or were the median serum levels of IL-6 different ( $p>0.05$ ). We did not establish significant dynamical changes in serum hepcidin and serum IL-6 concentrations during pregnancy in either of the two groups ( $>0.05)$.

Correlation analysis demonstrated that serum concentrations of IL-6 were significantly negatively related to the values of serum $\mathrm{Fe}(\mathrm{r}=-0.697 ; \mathrm{p}=0.006)$ and SatTf $(r=-0.598 ; p=0.024)$ in the high-risk pregnancies at the beginning of the second trimester (Table 2). According to the regression models, which are represented in Figures 1 and 2, a one-unit increase in serum IL-6 diminishes the value of serum Fe by 4.62 units and that of SatTf by 6.85 units.

At the later stage of gestation, serum hepcidin concentrations were found to be significantly 
positively related to those of IL-6 $(r=0.558 ; \mathrm{p}=0.038)$ in the low-risk pregnancies, while in the group of high-risk pregnancies serum hepcidin did not show significant correlation to the serum levels of IL-6 $(\mathrm{r}=-0.166 ; \mathrm{p}=0.571)$.

In the high-risk pregnancies, serum hepcidin showed significant inverse correlation to $\mathrm{Hb}$ concentration $(\mathrm{r}=-0.646 ; \mathrm{p}=0.023)$ and Hct $(\mathrm{r}=-0.654$; $\mathrm{p}=0.021)$ at the beginning of the third trimester, whereas serum levels of IL- 6 were found to be significantly positively related to the values of $\mathrm{Hb}$ concentration $(\mathrm{r}=0.685 ; \mathrm{p}=0.014)$. As indicated by the regression models, a one-unit increase in serum hepcidin diminished the value of $\mathrm{Hb}$ concentration by 0.17 units (Figure 3) and that of Hct - by 0.0006 units (Figure 4). Our results showed that for one-unit increase in serum IL-6, the value of $\mathrm{Hb}$ concentration increased by 8.24 units (Figure 5).

\section{Discussion}

Comparative assessment of parameters of iron homeostasis between the two study groups revealed significantly higher median value of serum Ferr in the high-risk pregnancies than the controls at the beginning of the second trimester. This could be indicative of greater amounts of stored iron due to the chronic inflammatory conditions presented in the group of high-risk pregnancies. It is well-known that synthesis of hepcidin is greatly stimulated in inflammatory conditions, which is mediated by IL-6 $6^{8,9}$. The hormone inhibits cellular release of iron, resulting in iron sequestration and increased storage of iron in macrophages of the reticuloendothelial system ${ }^{2,4,9}$. However, neither serum concentrations of hepcidin nor of IL-6 showed significant differences between the study groups in our research. Besides, serum Ferr is an acute-phase reactant and its levels could be elevated regardless of iron stores in the settings of chronic inflammatory conditions and hyperthyroidism ${ }^{25}$.

The significantly lower median value of TIBC in the study group of high-risk pregnancies vs. the low-risk pregnancies at the beginning of the second trimester points to a greater iron saturation of the transport protein transferrin and lower serum iron-binding potential. This can be inferred from the fact that the TIBC represents a measure of the available, unoccupied binding sites for iron on the plasma protein transferrin ${ }^{22,28}$. Along with the higher values of serum Ferr, lower values of TIBC in the high-risk pregnancies at the beginning of the second trimester were in accordance with the literature data on the inverse relationship between the TIBC and the amount of iron stores ${ }^{28}$. The TIBC has been reported to diminish in chronic inflammatory conditions ${ }^{28}$, as was the case with high-risk pregnancies in our study.
Longitudinal evaluation of parameters of iron metabolism in our study showed a significant decrease in serum Ferr and SatTf, and a significant rise in TIBC with the progress of pregnancy, which sup-

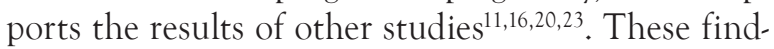
ings could reflect the physiologic hemodilution and elevated demands for iron, which affect the measures of iron status during pregnancy ${ }^{23}$. The significant $d y$ namical changes in SatTf, were not confirmed over the course of high-risk pregnancies. We suggest that this result may be attributed to the response of serum $\mathrm{Fe}$, as a negative acute-phase reactant $\mathrm{t}^{28}$, to the chronic inflammatory processes observed in the study group of high-risk pregnancies.

Our findings on serum hepcidin dynamics are not consistent with the results of most previous studies showing progressive reduction in the serum hepcidin levels throughout pregnancy ${ }^{11,19,20}$. Hepcidin has been found to decrease significantly at late-pregnancy, whereas the follow-up period in our study did not cover the end of pregnancy. It is most likely that significant decrease in the serum hepcidin concentration is present in the final four weeks of pregnancy. However, in our study of pregnant women within 16-32 weeks of gestation, we did not establish any significant changes in serum hepcidin. Data, similar to our results, were obtained by Welke et al (2017) in a longitudinal analysis of serum hepcidin concentrations between the second and third trimesters in women with high-risk pregnancies ${ }^{16}$.

The lack of significant dynamical changes in serum hepcidin during low-risk and high-risk pregnancies in our study formed a contrast to the significant changes in parameters of iron metabolism observed longitudinally. We speculate that this discrepancy may be attributed to a dominant effect of increased erythropoietic activity and inflammatory signals that counteract the effects of iron signals on hepcidin secretion.

Our results clearly indicated that as serum IL-6 levels increased, serum concentrations of Fe and SatTf decreased in high-risk pregnancies. The negative relationship observed is likely to reflect the decreased release of iron into plasma from macrophages under inflammatory conditions. Nemeth et al (2004) showed that IL-6 infusion induces a significant decrease in the serum Fe levels and SatTf in human volunteers. The effect is known to be exerted by hepcidin ${ }^{9}$, but no consistent relationship was found between the serum levels of Fe and hepcidin in our study.

The positive relationship between the serum concentrations of hepcidin and IL- 6 observed in the group of low-risk pregnancies points to the regulatory influence of IL-6, a potent inducer of hepcidin synthesis ${ }^{8,9}$. In most studies of uncomplicated pregnancies, hepcidin levels have not been shown to correlate 
with IL-6 and C-reactive protein (CRP), which indicate inflammation ${ }^{10,19,29}$. Conversely, a positive correlation between serum hepcidin and CRP has been found in a large study involving mostly uncomplicated pregnancies ${ }^{21}$.

Our findings demonstrated that as the serum levels of hepcidin increased, the values of $\mathrm{Hb}$ concentration and Hct became lower in women with high-risk pregnancies. These negative relationships were in accordance with our expectations. In chronic inflammation, hepcidin production is stimulated, which could result in inhibition of intestinal iron absorption and sequestration of iron in macrophages ${ }^{2,4,30}$. This would ultimately lead to a decreased supply of iron for hemoglobin synthesis. However, we did not observe a significant relationship between the serum levels of the inflammatory marker IL- 6 and hepcidin in the group of high-risk pregnancies at any stage of gestation. In some studies involving high-risk pregnancies inflammatory markers were positively correlated with serum hepcidin ${ }^{14,17}$, whereas in other studies there was no relationship between the serum levels of IL- 6 and hepcidin during pregnancy ${ }^{15,16}$. These results provide evidence that other hepcidin-regulating signals may override inflammation in the regulation of hepcidin synthesis and secretion in pregnancy ${ }^{16}$.

\section{Conclusions}

There are significant relationships of serum hepcidin and IL-6 to parameters of iron metabolism in pregnancy. Comparisons of iron status indicators between the two study groups revealed significant differences in relation to the serum concentrations of Ferr and the TIBC, possibly indicating greater stores of iron and lower iron-binding potential of serum in women with high-risk pregnancies. Besides, longitudinal assessment has shown a significant decrease in the serum levels of Ferr and a rise in the TIBC found in both low-risk and high-risk pregnancies. Due to the limitations of this study in view of the number of examined women, we cannot make a definitive conclusion about the appropriateness of iron supplementation in women with high-risk pregnancies. It is well known that in settings of chronic inflammation and abundant iron stores, iron supplementation provides an excess of free iron, which is a potent pro-oxidant. Correlation and regression analyses have demonstrated negative effects of hepcidin on the values of $\mathrm{Hb}$ concentration and Hct in women with high-risk pregnancies. These findings pose the question about the need to determine serum hepcidin concentrations in cases of anemia during high-risk pregnancies. The results could be used to optimize iron supplementation in women with high-risk pregnancies, because patients with elevated levels of hepcidin are at risk of ineffective response to oral iron supplementation. A significant positive relationship between the serum concentrations of hepcidin and IL-6 was confirmed in the low-risk pregnancies, but we consider that further research is needed to completely elucidate the complex and multifactorial regulation of hepcidin secretion during pregnancy. Our findings imply that serum hepcidin levels may be a possible useful marker for determination of the appropriate time of iron supplementation in women with high-risk pregnancies.

\section{Author Contributions}

T.V.P.-M. and B.K.R. participated in the conception and design of the study and interpretation of the data, B.P.B. contributed to acquisition of the data, M.A.A., P.V.D., and P.D.L. determined the laboratory data, T.V.P.M. participated in the analysis of the data and wrote the manuscript, and B.K.R. reviewed the manuscript.

\section{Compliance with Ethics Requirements:}

„The authors declare no conflict of interest regarding this article"

"The authors declare that all the procedures and experiments of this study respect the ethical standards in the Helsinki Declaration of 1975, as revised in 2008(5), as well as the national law. Informed consent was obtained from all the patients included in the study"

"No funding for this study"

\section{Acknowledgements}

This work was supported by Medical University Pleven, Bulgaria [research project 4/2015].

We would like to thank Mrs Yanka Tzvetanova for her assistance with the English translation of this paper.

\section{REFERENCES}

1. Kemna EH, Tjalsma H, Willems HL, Swinkels DW. Hepcidin: from discovery to differential diagnosis. Haematologica. 2008;93(1):90-97.

2. Nemeth E, Ganz T. The role of hepcidin in iron metabolism. Acta Haematologica. 2009;122:78-86.

3. Bergamaschi, G. Villani. L. Serum hepcidin: a novel diagnostic tool in disorders of iron metabolism. Haematologica. 2009;94(12):1631-1633.

4. Kroot JJ, Tjalsma H, Fleming RE, Swinkels DW. Hepcidin in human iron disorders: diagnostic implications. Clinical Chemistry. 2011;57(12):1650-1669.

5. Nicolas G, Bennoun M, Porteu A, et al. Severe iron deficiency anemia in transgenic mice expressing liver hepcidin. Proceedings of the National Academy of Sciences of the United States of America 2002;99: 4596-4601.

6. Young MF, Griffin I, Pressman E, et al. Maternal hepcidin is associated with placental transfer of iron derived from 
dietary heme and nonheme sources. The Journal of Nutrition. 2012;142: 33-39.

7. Basu S, Kumar N, Srivastava R, Kumar A. Maternal and cord blood hepcidin concentrations in severe iron deficiency anemia. Pediatrics $\mathcal{E}$ Neonatology. 2016;57(5): 413-419.

8. Nemeth E, Valore EV, Territo M, Schiller G, Lichtenstein A, Ganz T. Hepcidin, a putative mediator of anemia of inflammation, is a type II acute-phase protein. Blood. 2003;101(7): 2461-2463.

9. Nemeth E, Rivera S, Gabayan V, et al. IL-6 mediates hypoferremia of inflammation by inducing the synthesis of the iron regulatory hormone hepcidin. The Journal of Clinical Investigation. 2004;113(9): 1271-1276.

10. Gyarmati B, Szabo E, Szalay B, et al. Serum maternal hepcidin levels 3 days after delivery are higher compared to those measured at parturition. The Journal of Obstetrics and Gynaecology Research. 2011;37: 1620-1624.

11. Finkenstedt A, Widschwendter A, Brasse-Lagnel CG, et al. Hepcidin is correlated to soluble hemojuvelin but not to increased GDF15 during pregnancy. Blood Cells, Molecules EO Diseases. 2012;48:233-237.

12. Toldi G, Stenczer B, Molvarec A, et al. Hepcidin concentrations and iron homeostasis in preeclampsia. Clinical Chemistry and Laboratory Medicine. 2010;48:1423-1426.

13. Dao MC, Sen S, Iyer C, Klebenov D, Meydani SN. Obesity during pregnancy and fetal iron status: Is hepcidin the link? Journal of Perinatology. 2013;33:177-181.

14. Garcia-Valdes L, Campoy C, Hayes H, et al. The impact of maternal obesity on iron status, placental transferrin receptor expression and hepcidin expression in human pregnancy. International Journal of Obesity. 2015;39(4):571-578.

15. Cao C, Pressman EK, Cooper EM, Guillet R, Westerman $\mathrm{M}$, O'Brien KO. Pre-pregnancy body mass index and gestational weight gain have no negative impact on maternal or neonatal iron status. Reproductive Sciences. 2016;23(5):613622.

16. Welke L, Koenig MD, Thomson JL, et al. Iron metabolism in African American women in the second and third trimesters of high-risk pregnancies. Journal of Obstetrics, Gynecologic E Neonatal Nursing. 2017;46(1):148-158.

17. Brunacci F, Rocha VS, De Carli E, Espósito BP, Ruano R, Colli C. Increased serum iron in preeclamptic women is likely due to low hepcidin levels. Nutrition Research. 2018;53: 32-39.

18. Koenig MD, Tussing-Humphreys L, Day J, Cadwell B, Nemeth E. Hepcidin and iron homeostasis during pregnancy. Nutrients. 2014;6: 3062-3083.
19. Van Santen S, Kroot JJ, Zijderveld G, Wiegerinck ET, Spaanderman ME, Swinkels DW. The iron regulatory hormone hepcidin is decreased in pregnancy: A prospective longitudinal study. Clinical Chemistry and Laboratory Medicine. 2013;51:1395-1401.

20. Flores-Quijano ME, Montalvo-Velarde I, Vital-Reyes VS, Rodríguez-Cruz M, Rendón-Macías ME, López-Alarcón M. Longitudinal analysis of the interaction between obesity and pregnancy on iron homeostasis: Role of hepcidin. Archives of Medical Research. 2016;47(7): 550-556.

21. Rehu M, Punnonen K, Ostland V, et al. Maternal serum hepcidin is low at term and independent of cord blood iron status. European Journal of Haematology. 2010;85:345-352.

22. Centers for Disease Control and Prevention. Recommendations to prevent and control iron deficiency in the United States. The Morbidity and Mortality Weekly Report Recommendations and Reports. 1998;47(RR-3):1-29.

23. World Health Organization, Centers for Disease Control and Prevention. Assessing the iron status of populations, 2nd ed. Geneva, World Health Organization, 2007: 54, 79, 88.

24. Asare K. Anemia of critical illness. Pharmacotherapy. 2008;28(10): 1267-1282.

25. Zimmermann MB. Methods to assess iron and iodine status. British Journal of Nutrition. 2008;99(Suppl. 3): S2-S9.

26. Howard CT, McKakpo US, Quakyi IA, et al. Relationship of hepcidin with parasitemia and anemia among patients with uncomplicated Plasmodium falciparum malaria in Ghana. The American Journal of Tropical Medicine and Hygiene. 2007;77:623-626.

27. Gambling L, Czopek A, Andersen HS, et al. Fetal iron status regulates maternal iron metabolism during pregnancy in the rat. American Journal of Physiology. Regulatory, Integrative and Comparative Physiology. 2009;296: R1063-R1070.

28. Andrews NC, Ullrich CK, Fleming MD. Disorders of iron metabolism and sideroblastic anemia, in Nathan and Oski's Hematology of Infancy and Childhood, 7th ed, Orkin SH, Nathan DG, Ginsburg D, Thomas Look A, Fisher DE, Lux SE (eds). Philadelphia (PA), Saunders Elsevier, 2009: 521570.

29. Schulze KJ, Christian P, Ruczinski I, et al. Hepcidin and iron status among pregnant women in Bangladesh. Asia Pacific Journal of Clinical Nutrition. 2008;17:451-456.

30. Tussing-Humphreys L, Pustacioglu C, Nemeth E, Braunschweig C. Rethinking iron regulation and assessment in iron deficiency, anemia of chronic disease, and obesity: introducing hepcidin. Journal of the Academy of Nutrition and Dietetics. 2012;112(3): 391-400. 